\title{
2008 Dünya Ekonomik Krizinin G20 Ülkeleri Ekonomik Performanslarına Etkisinin AHP ve VIKOR Yöntemleriyle Değerlendirilmesi ${ }^{1}$
}

\author{
Mustafa SOBA*, Feyza ALTINTAŞ** \\ ÖZ
}

Bu çalışmada, 2008 dünya ekonomik krizi dönemindeki, ekonomideki iniş çıkışları yansıtabileceği düşünülen, 2003-2013 yılları arasındaki süreç ele alınmıştır. G20 ülkelerinin ekonomik performansları, 9 iktisadi kriter yardımıyla belirlenmiştir. Dünya ekonomisinin büyük bir bölümünü elinde bulunduran G20 ülkeleri ekonomilerinin, 2008 küresel krizi döneminde ne gibi değişikliklere uğradığ 1 ölçülerek, bu ülkelerin kriz dönemindeki ekonomik hayatlarıyla ilgili yorum yapılmıştır. Çok kriterli karar verme yöntemlerinden AHP (Analytic Hierarchy Process) ve VIKOR (Vise Kriterijumska Optimizacija I Kompromisno Resenje) yöntemi kullanılarak uygulama yapılmıștır. AHP yöntemi yardımıyla, kriterlere ağılık değeri atanarak, VIKOR yöntemine temel oluşturulmuştur. Çalışmada VIKOR yöntemi, alternatifler arasındaki sıralamayı ve uzlaşık çözümü elde etmeye yaradığı için kullanılmıştır. Uygulama sonucunda G20 ülkeleri içerisinde ekonomik performans açısından ideal uzlaşık çözüm ve alternatiflerin sıralaması, 2003-2013 yılları arasında her yıl için ayrı ayrı elde edilerek yorumlanmıştır.

Anahtar Kelimeler: Ekonomik Kriz, G20, Çok Kriterli Karar Verme, AHP, VIKOR

JEL Sınıflandırması: G01, 010, M29

\section{Evaluation of the Impact of 2008 World Economic Crisis on G20 Countries' Economic Performance by AHP and VIKOR Methods}

\begin{abstract}
In this study, the process between the years 2003-2013, which is thought to reflect the fluctuations in the economy in the period of 2008 world economic crisis, has been discussed. The economic performances of G20 countries were determined with the help of 9 economic criteria. The economies of the G20 countries, which hold a large part of the world economy, were measured in the period of the 2008 global crisis and the economic life of these countries in the crisis period was evaluated. Multi - criteria decision - making methods were performed by using AHP (Analytic Hierarchy Process) and VIKOR (Vise Kriterijumska Optimizacija I Kompromisno Resenje) method. With the help of AHP method, by assigning weight value to the criteria, VIKOR method is formed. In this study, VIKOR method is used because it serves to obtain the sorting between the alternatives and the solution around. As a result of the implementation, the ideal settlement and alternative alternatives in terms of economic performance in G20 countries were obtained and interpreted separately for each year between 2003-2013.
\end{abstract}

Keywords: Economic Crisis, G20, Multi-Criteria Decision Making, AHP, VIKOR

JEL Classification: G01, 010, M29

Araştırma Makalesi - Geliş Tarihi / Received: 09.02.2017 Kabul Tarihi / Accepted: 25.10.2018

\footnotetext{
${ }^{1} \mathrm{Bu}$ makale, Feyza ALTINTAŞ’ın Uşak Üniversitesi Sosyal Bilimler Enstitüsü İşletme Bölümü'nde 2016 y1lında sunmuş olduğu "2008 Dünya Ekonomik Krizinin G20 Ülkeleri Ekonomik Performanslarına Etkisinin Çok Kriterli Karar Verme Yöntemleriyle Değerlendirilmesi” başlıklı Yüksek Lisans Tezinden türetilmiş ve düzenlenmiştir.

* Doç. Dr., Uşak Üniversitesi, İktisadi ve İdari Bilimler Fakültesi, İşletme Bölümü, mustafa.soba@usak.edu.tr, ORCID: 0000-0001-9008-6474

** Yüksek Lisans Mezunu, Uşak Üniversitesi, SBE İşletme Anabilim Dalı, feyza.altintas@hotmail.com, ORCID: 0000-0003-4961-9528
} 


\section{GİRIŞ}

Ülke vatandaşlarının refah içerisinde yaşaması, uygulanan doğru iktisadi politikalarla sağlanabilir. Dolayısıyla ülkelerin gücü de ekonomik performanslarının yüksekliği ile ilişkilendirilir. $\mathrm{Bu}$ nedenle ülkeler küresel anlamda rekabet edebilmek için, iktisadi alanda başarısını arttırmalıdır. Ekonomik gücün birinci derecede önem arz ettiği günümüzde, ekonomik performansın ölçülmesi de ihtiyaç haline gelebilmektedir. İktisadi güç, önemli bir gösterge olmasına rağmen, yapılan literatür araştırmasında; çok kriterli karar verme yöntemlerinin, ekonomik performans ölçümü konusunda kullanımına, sınırlı sayıda yer verildiği görülmüştür. Bu nedenle bu konu ile ilgili kısıtlı sayıda çalışma ile karşılaşılmıştır. Bu çalışma, az sayıda veri kullanılarak yapılan çalışmalara kıyasla, daha kapsamlı ve geniş anlatımlı bir şekilde oluşturulmuştur. Bu çalışmada, ekonomik performans ölçümü yapabilmek için, 9 tane kriter belirlenmiş̧ir. Bu kriterler; GSYH, yıllık enflasyon oranı, yıllık faiz oranı, GSYH reel büyüme oranı, kişi başına düşen GSYH, işsizlik oranı, cari işlemler dengesi/GSYH, dış ticaret hacmi ve devlet brüt borç stoku/GSYH olarak oluşturulmuştur. Bu kriterler, Avrupa Birliği'nin iktisadi güç göstergesi olarak oluşturduğu Mastricht Kriterleri'ni de kapsayan, 7 kişilik iktisadi alanda uzman kişinin fikriyle ortaya koyulmuştur. Çalışmanın amacı; Türkiye başta olmak üzere, G20 ülkelerinin 2008 küresel ekonomik krizinden nasıl etkilendiğini ve kriz dönemindeki ekonomik performans sıralamasını, AHP ve VIKOR yöntemleriyle tespit etmeye çalışmaktır. İçerisinde Türkiye yer aldığ1 için G20 grubu seçilmiş̧tir. Yöntemler seçilirken uygulamanın amac1 göz önünde bulundurulmuştur. VIKOR yöntemi uygulanmadan önce, AHP yöntemi uygulamas1 yapılarak, kriter ağırlıkları belirlenmiştir. Bu ağırlık değerleri ile VIKOR yöntemi uygulaması yapılmıştır. Kapsamlı bir dönemi içeren çalışma, 2008 küresel krizi döneminde, Türkiye ve diğer G20 ülkelerinin iktisadi güçleri hakkında yorum yapılabilmesini amaçlamaktadır. Bu çalışmanın, yapılacak olan benzer konu ve yöntem uygulamalarına katkı sağlayacağı ön görülmektedir.

Amerika Birleşik Devletlerinde bulunan Lehman Brothers Inc. adlı yatırım bankası batmış ve iflasını açıklamak için başvuruda bulunmuştur. Bu olayın yaşandığı tarih krizin başlangıcı olmasa da, krizin varlığını ve etkisinin büyüklüğünü dünya kamuoyunun görmesinde başrol oynamıştır (Akman, 2010). ABD konut piyasasında, 2007 yılı ortalarında başlayan kriz, hızlı bir şekilde diğer ülkeleri etkilemiş ve finans sektöründeki kriz reel sektöre yayılmış, finansal kuruluşlardan bazıları iflas ederken, bazıları da ulusal hükümetlerin yardımıyla kurtarılmıştır (Hull, 2013). Krizin tesirinin etkileyici olduğu anlaşılınca; bu kriz, 1929 Krizini anımsatmış ve pek çok kurum ve kişi ile birlikte, uluslararası para fonu olan IMF de bu durumu "Büyük Bunalımdan sonra yaşanan en büyük finansal kriz" olarak adlandırmışlardır (Ferguson, 2009). Herhangi bir gayrimenkul satın alabilmek için bireylere veya tüzel kişilere verilen borç; mortgage olarak adlandırılır (Saunders ve Cornett, 2001). ABD'de meydana gelen ekonomik krizin temelinde, ülkenin ekonomiyi canlandırmak için ödeme gücü düşük kişilere mortgage kredisinin verilmesine izin vermesi sonucunda, finansal kesimin girdiği büyük risk vardır (Altuntepe, 2013). En kritik sorunlardan diğeri, kriz sürecinde banka ve brokırların sahip olduğu varlıkların türü, değeri, miktarı ve bu değerlerin kimlerle ilgili olduğu hakkındaki şeffaflık eksikliğidir. Bu sorunlar, türev denilen bazı kompleks ticari işlem sözleşmelerine sahip olan, özellikle Lehman benzeri firmaların batması sonrasında oluşan risk hesaplamasını ve kolay analiz yapılması şansını ortadan kaldırmıştır (Wasserstom, 2008). Mortgage kredisi kullanıcılarının geri ödemelerinde, faizlerin yükselmesinin de neden olduğu aksaklıklar ortaya çıkmıştır. Bu durum sonucunda kişiler, evlerini bankaya iade etmiş ve ödeme yapmaktan kurtulmuştur. Bankaların da kredi geri ödemelerini, diğer finansal kuruluşlara satmasıyla, bu konutlara ait sermaye piyasası araçları gelişmiştir. Bu nedenle de kriz tüm finansal kuruluşları etkisi altına almış ve çoğu kuruluşun iflasına neden olmuştur (Alantar, 2008).

Yirmi Ülke Grubu (G20-The Group of Twenty), küresel ekonomik istikrarın sağlanarak, teşvik edilmesi ve sürdürülebilir bir ekonomiye sahip olabilmek amacıyla, gelişmekte olan ve gelişmiş ülkeler arasında ekonomik politikalarda iş birliği yapılması için kurulmuş olan 
platformdur. G20'ye üye ülkelerin toplam nüfusu; dünya nüfusunun üçte ikisini oluştururken, dünya ekonomisinin $\% 85$ 'ini elinde bulundurmaktadır. Dünya ticaretinin ise $\% 75$ 'i bu gruba üye ülkeler tarafindan gerçekleştirilmektedir (Selim, Purtaş ve Uysal, 2014). G20 platformunu oluşturan ülkeler; Türkiye, ABD, Fransa, Endonezya, Almanya, İngiltere, Arjantin, Kanada, Avustralya, Suudi Arabistan, Brezilya, Güney Afrika, Güney Kore, Meksika, İtalya, Hindistan, Japonya, Çin, Rusya ve Avrupa Birliği Komisyonudur (TCMB, 2015). AB komisyonu adı altında; bağımsız olarak G20 içerisinde yer almayan diğer Avrupa Birliğine üye ülkeler temsil edilmektedir. G20 platformu, dünya finansal istikrarını hedeflemenin yanında, ekonomik bunalımlarda işbirliği yapmayı ve krizin verdiği hasara çözüm aramayı hedeflemektedir. Küresel kriz öncesinde küresel dengesizlikler, finansal reformlar başta görüşülen konular iken, kriz sonrasında alınabilecek önlemler, stratejiler, krizlerin etkisinin en aza indirilmesi ve bankacılık düzenlemeleri gibi konular önemli yer tutmaya başlamıştır (Tarım, 2011).

\section{LITERATÜR ARAŞTIRMASI}

Korhonen ve Topdaği (2003), AHP yöntemini derinlemesine incelemişlerdir. AHP yöntemi uygulanarak yapılacak çalışmanın kayıplarını ve kazanımlarını ele almışlardır. Ada, Kazançoğlu ve Aracıoğlu (2005), İzmir'de bir perakende firmasının birlikte çalışacağı tedarikçi firmanın seçimi için, Baykal (2007), çalışmasında personel seçimi problemi üzerine bir uygulama yapmıştır. Bu çalışma için belirlediği kriterleri ağırlıklandırmak için, Chiu ve Chen (2007) ise fikri mülkiyet sayılan patent sistemi ile ilgili değerlendirme yapmak amaciyla, AHP yöntemini kullanmışlardır. Jablonsky (2007), üretim birimlerinin verimliliğini arttırmak için AHP yöntemin nasıl uygulanabileceğini göstermiştir. Ünal (2010), insan kaynakları yöneticisi seçimi probleminde, Mikaeil, Yousefi ve Ataei (2011), karbonat kayalar arasında dikilmeye en uygun olanın seçilmesi konusunda, Bulanık AHP ve TOPSIS yöntemlerini kullanmışlardır. Soba ve Bildik (2013), çalışmalarında ilçelerde fakülte kuruluş yeri seçimi için, AHP yönteminden faydalanmışlardır. Ar, Baki ve Özdemir (2014), otel sektörü için kuruluş yeri seçimi konusunda, Bulanık AHP ve VIKOR yöntemlerini kullanarak bir uygulama yapmışlardır. Can ve Arıkan (2014), savunma sanayi firması için altyüklenici seçilmesi problemini ele aldığı çalışmasında, AHP ve PROMETHEE II yöntemlerini birlikte kullanmıştır. Yurdakul ve İpek (2005), malzeme taşıma sistemlerinin seçilmesinde, TOPSIS ve AHP yöntemini kullanmışlardır. Ustasüleyman (2009), AHP ve TOPSIS yöntemleri yardımıyla, bankacılık sektöründeki hizmet kalitesini değerlendirmiştir. Soner ve Önüt (2006), tedarikçi problemini değerlendirmesini ELECTRE ve AHP yöntemleri ile yapmışlardır. Perçin ve Ayan (2010), AHP ve Bulanık PROMETHEE yöntemlerini birlikte ele alarak, Esnek Üretim Sistemleri'nin (EÜS) seçiminde kullanmışlardır. Aydın, Öznehir ve Akçalı (2009), Ankara'da optimal hastane yeri seçimi için AHP yöntemini kullanmışlardır. Sakthivel, Ilangkumaran, Gaikwad (2015) AHP ve TOPSIS yöntemlerini hibrit model şeklinde kullanıp En iyi biyodizel harmanlama seçimi problemi üzerinde çalışmışlardır. Sekhar, Patwardhan ve Vyas (2015), Delphi-AHP-TOPSIS yöntemlerini bir KOBİ örneği üzerinde uygulamışlardır. Tyagi, Kumar ve Kumar (2014), tedarik zinciri yönetimi problemi çözümü için AHP ve TOPSIS yöntemlerini kullanmışlardır.

Tzeng, Lin ve Opricovic (2005), yakıt seçimi yapmak için, VIKOR ve TOPSIS yöntemlerini kullanmışlardır. Chu vd. (2007), bilgi toplumlarının grup karar analizinde, VIKOR, TOPSIS ve (SAW) yöntemlerinin uygulanabilir olduğunu göstermeye çalışmışlardır. Opricovic ve Tzeng (2007), bir nehir üzerinde hidroelektrik enerjisi elde etmek için kurulacak baraj yapılarının seçimini yapabilmek amacıyla VIKOR, PROMETHEE, TOPSIS ve ELECTRE yöntemleriyle kıyaslamalı olarak uygulayıp en uygun alternatif seçimini yapmışlardır. Ertuğrul ve Karakaşoğlu (2008), VIKOR yönteminden, bir bankanın şubeleri arasındaki üstünlük sıralamasını elde etmek için faydalanmışlardır. Büyüközkan ve Ruan (2008), ERP yazılımı seçimi konusunda, Chen ve Chen (2008), üniversite seçimi konusunda, 
Mohanty ve Mahapatra (2014), optimal dizayn edilmiş tasarım ürün seçiminde, Özden (2012), Türkiye ile AB'ye üye ülkelerin ekonomik performanslarının sıralanmasında, Chen ve Wang (2009), bilgi teknolojileri ve bilgi sistemleri seçimi konusunda, VIKOR yöntemini kullanmışlardır. Göktürk vd. (2011), VIKOR yöntemini, makine imalat sektöründeki bir firmanın tedarikçileri arasında en uygun seçimi yapabilmek için kullanmışlardır. Kaya, Çetin ve Kuruüzüm (2011), VIKOR yöntemiyle Avrupa Birliğine (AB) üye ve aday ülkelerin yaşam kalitesini analiz etmişlerdir. Özden, Başar ve Kalkan (2012), çalışmasında BIST(Borsa İstanbul)'te işlem gören çimento şirketlerinin ekonomik performanslarını analiz etmişlerdir. Karaatl1, Ömürbek ve Köse (2014), 2012-2013 sezonunda Süper Lig'de oynayan futbolcu performanslarını değerlendirmişlerdir. Uygulamada TOPSIS ve VIKOR yöntemlerini kullanmışlardır. Kılıçoğulları, Özcan ve Ertuğ (2009), akaryakıt istasyonu seçimi problemi için, çok kriterli karar verme yöntemlerinden ELECTRE ve TOPSIS yöntemleriyle uygulama yapmışlardır. Gök (2015), çalışmasında G20 Ülkelerinin enerji göstergeleri bakımından sıralamasını yapmak için çok kriterli karar verme yöntemlerini kullanmıştır.

Yapılan literatür taramasından yola çıkarak, çok kriterli karar verme yöntemleriyle ülkelerin ekonomik performans ölçütlerinin sıralandığı ve yorumlandığı kısıtlı sayıdaki çalışmaların yanında bu çalışmanın, literatüre bir kazanım olacağı düşünülmektedir.

\section{3. ÇOK KRITERLİ KARAR VERME YÖNTEMLERI}

Karşılaşılan problemler sonucunda alternatifler arasından en uygun seçimi yapmak ve problemleri çözüme kavuşturmak için oluşturulan yöntemler "Çok Kriterli Karar Verme Yöntemleri” adı altında toplanmaktadır (Ballı, Karasulu ve Korukoğlu, 2007). Bu çalışmada ÇKKV yöntemlerinden AHP ve VIKOR yöntemleri; kriterlerin ağırlık değerlerini hesaplayarak, uzlaşık çözüm yanında uzlaşık çözüme yakın çözümleri de elde etmek için seçilmiştir.

\subsection{AHP Yöntemi}

Karar verici pozisyonundaki grubun veya bireyin, öncelikli isteklerini göz önünde bulundurarak, nicel ve nitel değişkenlerin birlikte değerlendirildiği yöntem "Analitik Hiyerarşi Süreci (AHP)" olarak tanımlanır (Dağdeviren, 2007). AHP yöntemi çözümünde uygulama aşamaları aşağıdaki gibidir (Wind ve Saaty, 1980; Güngör ve İşler, 2005; Tyagi, Kumar ve Kumar, 2014; Sakthivel, Ilangkumaran ve Gaikwad, 2015):

1-Karar hiyerarşisi oluşturulur. edilir.

2-Satty (1980)’nin geliştirmiş olduğu 1-9 ölçeği kullanılarak karşılaştırma matrisi elde

3-Normalleştirilmiş matris belirtilir.

4-Tutarlılık analizi yapılır.

Matrislerin tutarlı olması, AHP uygulamasının geçerli olup olmayacağını belirler. Matrisin "Tutarlılık Göstergesi” (Consistency Index-CI), eşitlik 1 kullanılarak çözülür (Sakthivel vd. , 2015).

(Eşitlik 1)

$$
C I=\frac{\lambda \max -n}{n-1}
$$


Eşitlikte yer alan $\lambda \max$ her faktörün önem derecesiyle karşılaştırma matrisindeki ilgili sütununun çarpılıp, elde edilen sonuçların toplanmasıyla ortaya çıkan ağırlık vektörü yardımıyla hesaplanmıştır. Ağırlıklandırılan vektör değerlerinin, göreli öncelik değerlerine bölünerek çıkan sonuçların aritmetik ortalamasının alınmasıyla öz değer ( $\lambda$ max) elde edilir (Özyörük ve Özcan, 2008).

Tutarlılık oranı (Consistency Ratio-CR), eşitlik 2 yardımıyla hesaplanır.

$$
C R=\frac{C I}{C R}
$$

(Eşitlik 2)

RI (Rastsallık Göstergesi), Tablo 1' de görüldüğü üzere n değerine göre değişir (Aydın, Öznehir ve Akçalı, 2009). Tutarlılık analizinde amaç, faktörlerin birbirine göre üstünlüğünün tutarlılığını ölçerken, bu faktörlerin birbirinden kaç kat önemli olduğunun yanında, oransal üstünlügün tutarlılığını da ortaya koymaktır (Saaty ve Özdemir, 2003). Tablo 1'te görüldügü üzere, 1-15 arası boyutlardaki matrisler için tasarlanmış olan, rastsallık göstergeleri verilmiştir (Kwiesielewicz ve Uden, 2004).

Tablo 1: 1-15 Ölçeği Rastsallık Göstergeleri

\begin{tabular}{|r|c|c|c|c|c|c|c|c|c|c|c|c|c|c|c|}
\hline $\mathrm{N}$ & 1 & 2 & 3 & 4 & 5 & 6 & 7 & 8 & 9 & 10 & 11 & 12 & 13 & 14 & 15 \\
\hline $\begin{array}{c}\text { Rastsallık } \\
\text { Göstergesi }\end{array}$ & 0 & 0 & 0,58 & 0,9 & 1,12 & 1,24 & 1,32 & 1,41 & 1,45 & 1,49 & 1,51 & 1,48 & 1,56 & 1,57 & 1,59 \\
\hline
\end{tabular}

Tutarlılık Oranı (CR) 0,1'den küçük olduğunda, ikili karşılaştırmalar ve matris tutarlı kabul edilebilir (Chan vd. , 2006). Sonuçta, alternatifler içerisinde en yüksek değere sahip olanı, alternatiflerin en iyisi olarak seçilebilir (Palaz ve Kovancı, 2008).

\subsection{VIKOR Yöntemi}

İlk olarak Serafim Opricovic tarafindan, 1998 yılında ortaya atılan VIKOR yöntemi, Opricovic ve Tzeng (2004) tarafından yapılan çalışmalar sonucunda kullanılmaya başlanmıştır (Bali, 2013). Yöntemin temelindeki amaç, ideal çözüme en yakın çözümü bulabilmeye çalışmaktır. Yöntem, karar vericilerin elde edilecek sonuç üzerinde kısmen etkili olmasına da imkân sağlamaktadır (Yıldız ve Deveci, 2013). VIKOR analizi sayesinde, alternatifler arasında bir sıralama belirlenebilir ve belirlenen kıstaslar altında çözüme ulaşılabilir. VIKOR yöntemi; alternatifler arasından en iyi çözüm ile en iyi çözüme yakın olan durumlarında elde edilmesini sağlayabilir (Ertuğrul ve Karakaşoğlu, 2008). VIKOR analizinin çözüm aşamaları yapılmış çalışmalarda şöyle sıralanmıştır (Opricovic ve Tzeng, 2004; Aghdaie, Zolfani ve Zavadskas, 2014; Mohanty ve Mahapatra, 2014; Akman, 2015):

1.Adım: Oluş̧urulan bütün kriterler içerisinden; $i=1,2, \ldots ., n$, olmak üzere, en kötü $f_{i}^{-}$ ve en iyi $f_{i}^{*}$ değeri elde edilir ve $i$. fonksiyonun faydasi;

$$
f_{i}^{*}=\max _{j} f_{i j} \quad, \quad f i^{-}=\min _{j} f_{i j} \quad \text { olarak tanımlanır. }
$$

2. Adım: $\mathrm{Sj}$ ve $\mathrm{Rj}$ değerlerinin hesaplanması, $\mathrm{j}=1,2, \ldots, \mathrm{j}$, wi kriterlerin ağırlıklarını göstermektedir. Ağırlıklar toplamının 1'e eşit olması gerekmektedir. 


$$
S_{j}=\sum_{i=1}^{n} w_{i}\left(f i^{*}-f i j\right) \prime\left(f i^{*}-f^{-}\right)
$$

(Eşitlik 3)

$$
\boldsymbol{R}_{i}=\max _{i}\left[w_{i}\left(f i^{*}-f i j\right) /\left(f i^{*}-f^{-}\right)\right]
$$

(Eşitlik 4)

Eşitlik 3 ve 4 yardımıyla hesaplanan $\mathrm{Sj}$ değeri; ortalama grup, Rj değeri; en kötü grup değerini, wi değeri ise, önem ağırlığını gösterir ve bu değer karar vericiye göre değișebilir.

3. Adım: $Q_{i}$ değerlerinin hesaplanabilmesi için gerekli olan $S_{j}$ ve $R_{j}$ değerleri eşitlik 5 ve 6 yardımıyla bulunur.

$$
\begin{aligned}
& S^{*}=\min _{j} S_{j}, \quad S^{-}=\max _{j} S_{j} \\
& R^{*}=\min _{j} R_{j}, R^{-}=\max _{j} R_{j}
\end{aligned}
$$

$\mathrm{Q}_{\mathrm{i}}$ değerleri tüm $\mathrm{j}=1,2, \ldots, \mathrm{J}$ için belirlenir.

$$
Q_{j}=v\left(S_{j}-S^{*}\right) /\left(S^{-}-S^{*}\right)+(1-v)\left(R_{j}-R^{*}\right) /\left(R^{-}-R^{*}\right)
$$

En yüksek düzeyde grup faydasını elde etmeye yarayan strateji ağırlığı $\mathrm{v}$ değeri olarak tanımlanırken, başka alternatif seçilmesi pişmanlığının ağırlığ ise (1-v) değeri ile ifade edilmektedir. $\mathrm{v}>0,5$ çoğunluk oyu, $\mathrm{v}=0,5$ ortak karar verme, $\mathrm{v}<0,5$ veto ile sonuçlanabilir (Ertuğrul ve Karakaşoğlu, 2008).

4.Adım: 2. ve 3. adımda belirtilen eşitlikler yardımıyla bulunan $Q_{j}, S_{j}$ ve $R_{j}$ değerleri, küçükten büyüğe sıralanır. Sıralama sonucunda elde edilen en küçük $Q_{j}$ değerini oluşturan birim, alternatifler arasından seçebilecek en iyi tercih olarak kabul edilir. gerekir:

5. Adım: Tercih edilecek en küçük $Q$ değerini seçebilmek için şu iki koşulu sağlaması

Koşul 1: Kabul edilebilir avantaj:

$\mathrm{Q}\left(\mathrm{a}^{\prime \prime}\right)$ - $\mathrm{Q}\left(\mathrm{a}^{\prime}\right) \geq \mathrm{DQ}$ (a" değeri, $\mathrm{Q}$ değerine göre sıralamada ikinci sırayı alan alternatif).

$\mathrm{DQ}=1 /(\mathrm{J}-1) \quad$ ("J" alternatif say1s1).

Koşul 2: Karar vermede kabul edilebilir istikrar:

Q değerleri küçükten büyüğe sıralandığında ilk sırada yer alan alternatif a', $S$ ve/veya $R$ değerlerine göre yapılan küçükten büyüğe sıralama sonucunda da en iyi alternatif kabul edilir. $\mathrm{Bu}$ koşulla uzlaşı çözüm karar verme sürecinde istikrarlıdır. Eğer bu iki durumdan bir tanesi sağlanmazsa şu aşamalar önerilir:

-Eğer C2 durumu sağlanmıyorsa a' ve a" alternatifleri, için $\mathrm{Q}(\mathrm{a}(\mathrm{M}))$,

-Eğer $\mathrm{C} 1$ durumu sağlanmıyorsa a', a", ..., a(M) alternatifleri ve değeri maksimum M

$-\mathrm{Q}\left(\mathrm{a}^{\prime}\right)<\mathrm{DQ}$ belirlenir.

En iyi alternatif, Q değerlerinin sıralanması sonucunda, minimum Q değerine sahip alternatiflerden biri olarak kabul edilir (Opricovic ve Tzeng, 2004). 


\section{UYGULAMA}

\subsection{Model}

G20 ülkelerinin ekonomik performanslarında etkili olduğu düşünülen 9 kriter, 7 kişilik uzman grubuyla birlikte karar vericinin alternatiflerden beklentisini yansitacak şekilde ortaya konulmaya çalışılmıştır.

Tablo 2: Uygulama Kriterleri

\begin{tabular}{|c|c|c|}
\hline Kriterler & Açıklama & En İyi-En Kötü fi* Seçimi \\
\hline GSYH & $\begin{array}{l}\text { Bir ülkede, belirli bir zamanda üretilen nihai } \\
\text { mal ve hizmetlerin piyasa değeri olarak } \\
\text { tanımlanabilir (Ertek, 2008). }\end{array}$ & $\begin{array}{l}\text { GSYH uygulama konusu gereği fayda } \\
\text { özelliğine sahip bir kriter olduğundan } \\
\text { VIKOR yöntemi uygulamasında en } \\
\text { iyi fi* değeri için, en yüksek GSYH' } \\
\text { ye sahip alternatif verisi seçilecektir. }\end{array}$ \\
\hline Enflasyon & $\begin{array}{l}\text { Toplam talebin, toplam arzdan fazla olması } \\
\text { sonucunda fiyatlar genel seviyesinde meydana } \\
\text { gelen artış olarak tanımlanabilir (Altınok, } \\
\text { 2004). }\end{array}$ & $\begin{array}{l}\text { Enflasyon, maliyet özellikli bir kriter } \\
\text { olduğundan, VIKOR yöntemi } \\
\text { uygulamasındaki en iyi fi* değeri } \\
\text { olarak, enflasyon oranı en düşük olan } \\
\text { alternatif verisi kullanılacaktır. }\end{array}$ \\
\hline Faiz Oranı & $\begin{array}{l}\text { Paranın kiralanarak, bunun karşılığında bir } \\
\text { bedel ödenir ve bu bedel faiz olarak } \\
\text { adlandırılabilir (Herrig ve Santomero, 1996). }\end{array}$ & $\begin{array}{l}\text { En iyi fi* değeri olarak, faiz oranı en } \\
\text { düşük olan alternatif verisi } \\
\text { kullanılacaktır. }\end{array}$ \\
\hline $\begin{array}{l}\text { GSYH } \\
\text { Reel } \\
\text { Büyüme } \\
\text { Oranı }\end{array}$ & $\begin{array}{l}\text { Büyüme oranı GSYH ile birebir ilişkilidir. Bir } \\
\text { ülkenin, belirli bir yıl içinde sahip olduğu } \\
\text { GSYH' nin, bir önceki yılda elde ettiği GSYH } \\
\text { ile oranlanması sonucunda büyüme oranı elde } \\
\text { edilir (Eğilmez, 2012). }\end{array}$ & $\begin{array}{l}\text { En iyi fi* değeri olarak, GSYH Reel } \\
\text { Büyüme oranı en yüksek olan } \\
\text { alternatif verisi kullanılacaktır. }\end{array}$ \\
\hline $\begin{array}{l}\text { Kişi } \\
\text { Başına } \\
\text { Düşen } \\
\text { GSYH }\end{array}$ & $\begin{array}{l}\text { Bir ülkede, bir yilda elde edilen toplam } \\
\text { GSYH' nin ülke nüfusuna bölünmesiyle elde } \\
\text { edilir. }\end{array}$ & $\begin{array}{l}\text { En iyi fi* değeri olarak, Kişi Başına } \\
\text { Düşen GSYH değeri en yüksek olan } \\
\text { alternatif verisi kullanılacaktır. }\end{array}$ \\
\hline $\begin{array}{l}\text { İşsizlik } \\
\text { Oranı }\end{array}$ & $\begin{array}{l}\text { Bir ülkede çalışabilir durumda olan aktif } \\
\text { nüfusun içerisinde olup, çeşitli nedenlerden } \\
\text { dolayı çalışmayanların aktif nüfusa oranı } \\
\text { olarak tanımlanabilir (Zaim, 1997). }\end{array}$ & $\begin{array}{l}\text { En iyi fi* değeri olarak, İşsizlik oranı } \\
\text { en düşük olan alternatif verisi } \\
\text { kullanılacaktır. }\end{array}$ \\
\hline $\begin{array}{l}\text { Cari } \\
\text { İşlemler } \\
\text { Dengesi }\end{array}$ & $\begin{array}{l}\text { Bir ülkenin yaptığı ekonomik faaliyetler } \\
\text { sonucunda, döviz girişleri ile döviz çıkışları } \\
\text { arasındaki fark olarak ifade edilebilir } \\
\text { (Obstfeld ve Rogoff, 1996). }\end{array}$ & $\begin{array}{l}\text { En iyi fi* değeri olarak, Cari İşlemler } \\
\text { Dengesi en yüksek olan alternatif } \\
\text { verisi kullanılacaktır. }\end{array}$ \\
\hline $\begin{array}{l}\text { Dış Ticaret } \\
\text { Hacmi }\end{array}$ & $\begin{array}{l}\text { Bir ülkenin, belirli bir dönemde yaptığı ithalat } \\
\text { ve ihracat miktarlarının toplamıdır (Grossman } \\
\text { ve Helpman, 2003). }\end{array}$ & $\begin{array}{l}\text { En iyi fi* değeri olarak, Dış Ticaret } \\
\text { Hacmi en yüksek olan alternatif verisi } \\
\text { kullanılacaktır. }\end{array}$ \\
\hline
\end{tabular}




\begin{tabular}{l|l} 
Devlet & Bir ülkenin kamu kesimini kapsayan (KIT'ler \\
Brüt Borç & hariç) birimlerin iç ve dış borçlarının toplamı \\
Stoku & demektir (Eğilmez, 2012).
\end{tabular}

Devlet Stoku demektir (Eğilmez, 2012).
En iyi fi* değeri olarak, Devlet Brüt Borç Stoku en düşük olan alternatif verisi kullanılacaktır.

\subsection{AHP Yönteminin Uygulanması}

VIKOR yöntemini uygulamaya başlamadan önce, kullanılacak olan kriterlere ait ağırlık değerlerini bulmak ve bu ağılık değerlerini de bilimsel bir yöntemle çözümlemek için, AHP yöntemi kullanılmıştır. Bu yöntem, çok kriterli karar verme yöntemleri içerisinde yer alır ve kriter ağırlık değerlerinin hiyerarşik sıralamasını yapabilmeye yardımcı olur. AHP Yönteminin basamaklarını uygulamaya başlamadan önce 7 kişilik uzman grubuyla birlikte belirlenen kriterlere ait ağırlık değerleri, grubun verdiği değerlerin geometrik ortalaması alınarak hesaplanmış ve ilk aşamanın temeli bu hesaplamalar ile elde edilmiştir. İlk olarak; Tablo 3'de görüldüğüu üzere kriterler arası ikili karşılaştırma matrisi oluşturulmuştur.

\section{Tablo 3: İkili Karşılaştırmalar Matrisi}

\begin{tabular}{|c|c|c|c|c|c|c|c|c|c|c|}
\hline \multirow{2}{*}{\multicolumn{2}{|c|}{ K DEĞERİ }} & $\begin{array}{l}\text { GSYH } \\
\text { (USD) }\end{array}$ & $\begin{array}{c}\text { Y1llık } \\
\text { Enflasyon } \\
\text { Oranı }\end{array}$ & $\begin{array}{l}\text { Y1ll1k } \\
\text { Faiz } \\
\text { Oranı }\end{array}$ & $\begin{array}{c}\text { GSYH } \\
\text { Reel } \\
\text { Büyüme } \\
\text { Oranı }\end{array}$ & $\begin{array}{c}\text { Kişi } \\
\text { Başına } \\
\text { Düssen } \\
\text { GSYH } \\
\text { (USD) }\end{array}$ & $\begin{array}{c}\text { İsssizlik } \\
\text { Oranı }\end{array}$ & $\begin{array}{c}\text { Cari } \\
\text { İşlemler } \\
\text { Dengesi / } \\
\text { GSYH }\end{array}$ & \begin{tabular}{l}
\multicolumn{1}{c}{ Dış } \\
Ticaret \\
Hacmi \\
(USD)
\end{tabular} & $\begin{array}{c}\text { Devlet } \\
\text { Brüt } \\
\text { Borç } \\
\text { Stoku / } \\
\text { GSYH }\end{array}$ \\
\hline & & $\mathrm{K} 1$ & $\mathrm{~K} 2$ & K3 & $\mathrm{K} 4$ & K5 & K6 & K7 & K8 & K9 \\
\hline GSYH (USD) & K1 & 1,00 & 3,00 & 3,00 & 3,00 & 1,00 & 5,00 & 5,00 & 3,00 & 5,00 \\
\hline Yıllık Enflasyon Oranı & $\mathrm{K} 2$ & 0,33 & 1,00 & 1,00 & 1,00 & 0,33 & 3,00 & 3,00 & 1,00 & 3,00 \\
\hline Y1llık Faiz Oranı & $\mathrm{K} 3$ & 0,33 & 1,00 & 1,00 & 1,00 & 0,33 & 3,00 & 3,00 & 1,00 & 3,00 \\
\hline $\begin{array}{c}\text { GSYH Reel Büyüme } \\
\text { Oranı }\end{array}$ & K4 & 0,33 & 1,00 & 1,00 & 1,00 & 0,33 & 3,00 & 3,00 & 1,00 & 3,00 \\
\hline $\begin{array}{c}\text { Kişi Başına Düşen } \\
\text { GSYH (USD) }\end{array}$ & K5 & 1,00 & 3,00 & 3,00 & 3,00 & 1,00 & 5,00 & 5,00 & 3,00 & 5,00 \\
\hline İşsizlik Oranı & K6 & 0,20 & 0,33 & 0,33 & 0,33 & 0,20 & 1,00 & 1,00 & 0,33 & 1,00 \\
\hline $\begin{array}{c}\text { Cari İşlemler Dengesi / } \\
\text { GSYH }\end{array}$ & K7 & 0,20 & 0,33 & 0,33 & 0,33 & 0,20 & 1,00 & 1,00 & 0,33 & 1,00 \\
\hline $\begin{array}{c}\begin{array}{c}\text { Diş Ticaret Hacmi } \\
\text { (USD) }\end{array} \\
\end{array}$ & K8 & 0,33 & 1,00 & 1,00 & 1,00 & 0,33 & 3,00 & 3,00 & 1,00 & 3,00 \\
\hline $\begin{array}{c}\text { Devlet Brüt Borç Stoku } \\
\text { / GSYH }\end{array}$ & K9 & 0,20 & 0,33 & 0,33 & 0,33 & 0,20 & 1,00 & 1,00 & 0,33 & 1,00 \\
\hline TOPLAM & & $\mathbf{3 , 9 2}$ & 10,99 & 10,99 & 10,99 & 3,92 & 25,00 & 25,00 & 10,99 & 25,00 \\
\hline
\end{tabular}

İkili karşılaştırmalar matrisinde bulunan her bir elemanın sütun toplamına bölünmesiyle Tablo 3'deki veriler elde edilmiştir. 
Tablo 4: Kriter Ağırlıkları

\begin{tabular}{|c|c|c|}
\hline K1 & GSYH & $\mathbf{0 , 2 4 4 6 8}$ \\
\hline K2 & Yillık Enflasyon Oranı & $\mathbf{0 , 0 9 9 1 5}$ \\
\hline K3 & Yıllık Faiz Oranı & $\mathbf{0 , 0 9 9 1 5}$ \\
\hline K4 & GSYH Reel Büyüme Oranı & $\mathbf{0 , 0 9 9 1 5}$ \\
\hline K5 & Kişi Başına Düşen GSYH & $\mathbf{0 . 2 4 4 6 8}$ \\
\hline K6 & İşsizlik Oranı & $\mathbf{0 , 0 3 8 0 2}$ \\
\hline K7 & Cari İşlemler Dengesi/GSYH & $\mathbf{0 , 0 3 8 0 2}$ \\
\hline K8 & Diş Ticaret Hacmi & $\mathbf{0 , 0 9 9 1 5}$ \\
\hline K9 & Devlet Brüt Borç Stoku/GSYH & $\mathbf{0 , 0 3 8 0 2}$ \\
\hline
\end{tabular}

Ortaya çıkan normalleştirilmiş matrisin satır ortalamaları ise, kriterlerin ağırlıklarını vermektedir. Elde edilen ağırlık değerleri Tablo 4'te görüldüğü gibidir.

Kriterlere ait ağırlık değerlerinin doğruluğunu ölçmek için tutarlılık oranı aşağıdaki gibi hesaplanmıștır. Öncelikle tutarlılık göstergesi (CI), 1. eșitlik yardımıyla, her faktörün önem derecesiyle karşılaştırma matrisindeki ilgili sütununun çarpılıp, elde edilen sonuçların toplanmasıyla ortaya çıkan ağırlık vektörü yardımıyla hesaplanmıştır.

Tutarlılık göstergesi aşağıdaki şekilde hesaplanmıştır:

$$
\mathrm{CI}=\frac{\lambda \max -\mathrm{n}}{\mathrm{n}-1}=0,01050
$$

RI değeri, kriter sayısına göre değişiklik gösterir. Uygulama 9 kriterden oluştuğu için, n=9'a denk gelen değer RI değeri olarak kabul edilmiştir. Hesaplanan tutarlılık göstergesi yardımıyla, tutarlılık oranı aşağıdaki şekilde hesaplanmıştır.

$$
\begin{gathered}
\mathrm{RI}=1,45 \text { (Tablo 1'e göre) } \\
C R=\frac{C I}{C R}=\frac{0,01050}{1,45}=0,00724<0,1 \text { 'dir. }
\end{gathered}
$$

Tutarlılık Oranı $<0,1$ bulunduğundan elde edilen ağırlık değerleri tutarlı kabul edilmiştir.

\subsection{VIKOR Yönteminin Uygulanması}

VIKOR Yöntemi; uygulamanın yapılma amaçlarından biri olan, alternatifler hakkında yorum yapabilmeyi sağlaması amacıyla seçilmiştir. Çünkü bu yöntem uzlaşık çözümü elde etmenin yanında uzlaşık çözüme en yakın çözümleri de sıralamalı olarak verdiğinden her alternatifin sıralamasının sorgulanmasını ve tartışılmasını sağlayacağı düşünülmüştür.

VIKOR yöntemi uygulanırken sadece 2006 yılına ait verilerle örnek çözümleme aşamaları verilmiş ancak kalan 10 yıla ait çözümlemelerin sonucu çalışmada gösterilmiştir. Belirlenen 20 alternatife ait 2006 yılı ekonomik verileri Tablo 5' te görüldüğg̈ gibidir. Bu 
veriler ve AHP yöntemiyle bulunan ağırlık değerleri, VIKOR yönteminin uygulanmasında kullanılmıștır.

Tablo 5: Alternatiflere İlişkin 2006 Yılı Ekonomik Verileri

\begin{tabular}{|c|c|c|c|c|c|c|c|c|c|c|}
\hline \multicolumn{2}{|c|}{$\begin{array}{c}\text { ÜLKELER / } \\
\text { VERILERR } \\
2006\end{array}$} & \multirow{2}{*}{$\begin{array}{c}\text { GSYH (USD) } \\
2.905 .400 .000 .000 \\
\end{array}$} & \multirow{2}{*}{$\begin{array}{c}\text { Y1llık } \\
\text { Enflasyon } \\
\text { Oranı }\end{array}$} & \multirow{2}{*}{$\begin{array}{c}\text { Yillik } \\
\text { Faiz } \\
\text { Oranı } \\
\\
3,08 \\
\end{array}$} & \multirow{2}{*}{$\begin{array}{c}\text { GSYH } \\
\text { Reel } \\
\text { Büyüme } \\
\text { Oranı } \\
\\
\\
3,9 \\
\end{array}$} & \multirow{2}{*}{$\begin{array}{c}\text { Kişi } \\
\text { Başına } \\
\text { Düşen } \\
\text { GSYH } \\
\text { (USD) }\end{array}$} & \multirow{2}{*}{$\begin{array}{c}\text { İşsizli } \\
\text { k } \\
\text { Oranı } \\
\\
10,2 \\
\end{array}$} & \multirow{2}{*}{$\begin{array}{c}\text { Cari } \\
\text { İşleml } \\
\text { er } \\
\text { Denge } \\
\text { si / } \\
\text { GSY } \\
\text { H } \\
\\
5,97 \\
\end{array}$} & \multirow{2}{*}{$\begin{array}{l}\begin{array}{l}\text { Dış Ticaret Hacmi } \\
\text { (USD) }\end{array} \\
2.044 .410 .000 .000 \\
\end{array}$} & \multirow{2}{*}{$\begin{array}{c}\text { Devlet } \\
\text { Brüt Borç } \\
\text { Stoku / } \\
\text { GSYH } \\
68,0\end{array}$} \\
\hline 1 & Almanya & & & & & & & & & \\
\hline 2 & Fransa & 2.327 .100 .000 .000 & 1,9 & 3,08 & 2,4 & 37.900 & 8,9 & $-0,56$ & 925.990 .000 .000 & 63,2 \\
\hline 3 & İngiltere & 2.486 .600 .000 .000 & 2,3 & 4,8 & 2,8 & 38.585 & 5,5 & $-2,84$ & 1.034 .370 .000 .000 & 42,7 \\
\hline 4 & İtalya & 1.874 .700 .000 .000 & 2,2 & 3,08 & 2,2 & 32.288 & 6,8 & $-1,47$ & 859.780 .000 .000 & 106,3 \\
\hline 5 & $\mathrm{ABD}$ & 13.855 .900 .000 .000 & 3,2 & 5,15 & 2,7 & 44.224 & 4,6 & $-5,82$ & 2.041 .370 .000 .000 & 63,6 \\
\hline 6 & Japonya & 4.356 .800 .000 .000 & 0,2 & 0,68 & 1,7 & 34.077 & 4,1 & 4,01 & 1.226 .320 .000 .000 & 186,0 \\
\hline 7 & Kanada & 1.310 .800 .000 .000 & 2 & 1,83 & 2,6 & 40.297 & 6,3 & 1,37 & 747.300 .000 .000 & 70,4 \\
\hline 8 & Avustralya & 781.500 .000 .000 & 3,6 & 4,06 & 2,7 & 37.887 & 4,8 & $-5,8$ & 1.165 .220 .000 .000 & 10,0 \\
\hline 9 & Güney Kore & 1.011 .800 .000 .000 & 2,2 & 4,5 & 5,2 & 20.917 & 3,5 & 0,35 & 634.820 .000 .000 & 29,3 \\
\hline 10 & Türkiye & 526.400 .000 .000 & 9,6 & 21,65 & 6,9 & 7.044 & 9 & $-6,02$ & 225.110 .000 .000 & 46,5 \\
\hline 11 & Arjantin & 262.800 .000 .000 & 10,9 & 6,42 & 8,4 & 6.852 & 10,2 & 2,73 & 80.730 .000 .000 & 61,8 \\
\hline 12 & Brezilya & 1.089.300.000.000 & 4,2 & 13,93 & 4 & 5.815 & 10 & 1,25 & 233.650 .000 .000 & 67,0 \\
\hline 13 & Çin & 2.793 .200 .000 .000 & 1,5 & 2,52 & 12,7 & 2.125 & 4,1 & 8,3 & 1.761 .180 .000 .000 & 31,5 \\
\hline 14 & Endonezya & 364.400 .000 .000 & 13,1 & 11,41 & 5,5 & 1.623 & 10,3 & 2,62 & 184.180 .000 .000 & 39,0 \\
\hline 15 & $\begin{array}{l}\text { Güney } \\
\text { Afrika }\end{array}$ & 261.200 .000 .000 & 4,7 & 7,14 & 5,6 & 5.267 & 23,6 & $-5,31$ & 136.170 .000 .000 & 31,0 \\
\hline 16 & Hindistan & 949.100 .000 .000 & 7 & 15,08 & 9,3 & 840 & 4,3 & $-1,01$ & 300.280 .000 .000 & 77,1 \\
\hline 17 & Meksika & 966.900 .000 .000 & 3,6 & 3,3 & 5 & 8.367 & 3,6 & $-0,81$ & 518.610 .000 .000 & 37,8 \\
\hline 18 & Rusya & 989.900 .000 .000 & 9,7 & 4,08 & 8,2 & 5.311 & 7,2 & 9,33 & 485.090 .000 .000 & 10,5 \\
\hline 19 & $\begin{array}{c}\text { Suudi } \\
\text { Arabistan }\end{array}$ & 376.400 .000 .000 & 1,9 & 6,92 & 5,6 & 14.079 & 6,3 & 26,34 & 281.110 .000 .000 & 25,8 \\
\hline 20 & $\begin{array}{c}\mathrm{AB} \\
\text { Komisyonu }\end{array}$ & 14.900 .400 .000 .000 & 2,2 & 3,08 & 3,6 & 30.147 & 8,4 & $-0,22$ & 9.477 .090 .000 .000 & 60,8 \\
\hline
\end{tabular}

VIKOR yöntemine göre öncelikle, kriterler arasında en iyi $\left(f_{i}^{*}\right)$ ve en kötü $\left(f_{i}^{-}\right)$değerleri belirlenir. $\mathrm{Bu}$ değerler belirlenirken dikkat edilmesi gereken husus; kriterlerin fayda ya da maliyet özellikli olmasıdır. Bu nedenle, maliyet özelliği taşıyan değerler en kötü fï olarak sınıflandırılır. Değerin yüksek olması fi* olarak sınıflandırmak için yeterli değildir. Değerin yüksek ya da düşük olmasının karar vericinin faydasına olduğunu gösteren değerler en iyi fi* olarak sinıflandirılır. 
Tablo 6: 2006 Yılı Verilerine Göre En İyi ve En Kötü fi Değerleri

\begin{tabular}{|c|c|c|}
\hline \multicolumn{2}{|c|}{ En İyi fi* ve En Kötü fi ${ }^{-}$Değerleri } \\
\hline SEÇENEKLER & $\mathbf{f i}^{*}$ & $\mathbf{f i}^{-}$ \\
\hline GSYH (USD) & 14.900 .400 .000 .000 & 261.200 .000 .000 \\
\hline Yıllık Enflasyon Oranı & 0,2 & 13,1 \\
\hline Y1llık Faiz Oranı & 0,68 & 21,65 \\
\hline GSYH Reel Büyüme Oranı & 12,7 & 1,7 \\
\hline Kişi Başına Düşen GSYH (USD) & 44.224 & 840 \\
\hline İşsizlik Oranı & 3,5 & 23,6 \\
\hline Cari İşlemler Dengesi / GSYH & 26,34 & $-6,02$ \\
\hline Dış Ticaret Hacmi (USD) & 9.477 .090 .000 .000 & 80.730 .000 .000 \\
\hline Devlet Brüt Borç Stoku / GSYH & 10 & 186 \\
\hline
\end{tabular}

Maksimum ve minimum fi kullanılarak, eşitlik 3 yardımıyla, Sj değerleri elde edilmiştir. Eşitlik 4 yardımıyla, $\mathrm{Rj}$ değerleri bulunur. Bu değerler elde edilirken 3. ve 4. eşitliklere de dikkat edileceği üzere, AHP yöntemi ile elde edilen ağırlık değerleri kullanılmıştır. Burada kriterlere atanmış olan ağırlık değerlerinin, alternatif kriter skorunu belirlemede ne oranda etkili olduğu görülebilir.

Örnek olarak; 2006 yılı ekonomik verileri kullanılarak, A1 yani Almanya alternatifinin GSYH kriteri için $S_{j}, R_{j}$ ve $Q_{j}$ değerlerinin nasıl hesaplandığı aşağıda gösterilmiştir.

Sj değerleri eşitlik 3 yardımıyla ve Tablo 4, 5 ve 6'daki veriler kullanılarak şu şekilde hesaplanmıştır:

$$
S_{j}=\frac{0,24468 x(14.900 .400 .000 .000-2.905 .400 .000 .000)}{(14.900 .400 .000 .000-261.200 .000 .000)}=0,20048
$$

$\mathrm{Bu}$ hesaplama 1. sıradaki alternatif ve yine ilk sıradaki kriter için yapılmıştır. Aynı şekilde 1. sıradaki alternatifle diğer kriterler için de sırasıyla hesaplama yapılarak satır toplamı alınmış ve A1 yani Almanya alternatifi için $S_{j}$ değeri 0,48135 olarak elde edilmiştir.

Rj değerleri eşitlik 4 yardımıyla ve Tablo 4, 5 ve 6'daki veriler kullanılarak şu şekilde hesaplanmıştır:

$$
R_{j}=\max \left[\frac{0,24468 x(14.900 .400 .000 .000-2.905 .400 .000 .000)}{(14.900 .400 .000 .000-261.200 .000 .000)}\right]=0,20048
$$

Denklemdeki "max" değeri; elde edilen $\mathrm{Sj}$ tablosunda, ilgili satırdaki maksimum değerdir. Bu değer o alternatif için $\mathrm{Rj}$ değeri kabul edilir. Hesaplama bütün alternatifler için aynı şekilde tekrarlanarak $\mathrm{Rj}$ tablosu elde edilmiştir.

Qj Tablo 6'daki en iyi ve en kötü $s_{i}$ ve $r_{i}$ verileri kullanılarak hesaplanmıştır. Burada dikkat edilmesi gereken, minimum grup pişmanlığını elde etmek için; en iyi si* ve ri* değerlerinin sıralamadaki en küçük değerler, en kötü si ve ri $^{-}$değerlerinin sıralamadaki en yüksek değerler olmasıdır. Eşitlik 7 yardımıyla ve Tablo 6' daki en iyi ve en kötü $s_{i}$ ve $r_{i}$ verileri kullanılarak şu şekilde hesaplanmıştır ( $\mathrm{v}=0,5$ için).

$$
\mathrm{Q}_{\mathrm{j}}=0,5(0,48135-0,23958) /(0,84304-0,23958)+(0,5)(0,20048-
$$




$$
0,08202) /(0,24468-0,08202)=0,56447
$$

$S_{j}, R_{j}$ ve $Q_{j}$ değerleri Tablo 7' de görüldüğ̈ üzere küçükten büyüğe sıralanmıştır. Sıralama sonrasında $\mathrm{C} 1$ koşulunu sağlayan alternatifler $Q\left(a^{\prime \prime}\right)-Q\left(a^{\prime}\right) \geq D Q$ denklemi kullanılarak bulunur.

$$
D Q=1 /(\mathrm{J}-1)=1 / 19=0,0526
$$

A5, A6, A20 alternatiflerinin kabul edilebilir avantaja sahip olduğu dolayısıyla C1 koşulunu sağladığ1 tespit edilmiştir. C2 koşulunu sağlayan alternatifler ise sıralama sonucunda aynı satırda yer alan alternatiflerdir. A3, A5, A20 alternatiflerinin C2 durumunu sağladığı görülmektedir.

C1 ve C2 koşullarını aynı anda sağlayan A5 ve A20 alternatifleri 2006 y1lı için uzlaşık çözümler olarak elde edilmiştir.

Tablo 7: 2006 Yılı Verilerine Göre $Q_{j}$ Değerinin Hesaplanması ve $S_{j}$, $R_{j}$ ve $Q_{j}$ Değerlerinin

\section{Siralanması}

\begin{tabular}{|c|c|c|c|}
\hline SIRA & $\begin{array}{c}\text { Sj } \\
\text { Değeri }\end{array}$ & $\begin{array}{c}\text { Rj } \\
\text { Değeri }\end{array}$ & $\begin{array}{c}\text { Qj } \\
\text { Değeri }\end{array}$ \\
\hline A1 & 0,48135 & 0,20048 & 0,56447 \\
\hline A2 & 0,50660 & 0,21015 & 0,61510 \\
\hline A3 & 0,49835 & 0,20748 & 0,60007 \\
\hline A4 & 0,55703 & 0,21771 & 0,68013 \\
\hline A5 & 0,28168 & 0,09013 & 0,05983 \\
\hline A6 & 0,48505 & 0,17622 & 0,49296 \\
\hline A7 & 0,49939 & 0,22714 & 0,66134 \\
\hline A8 & 0,53189 & 0,23598 & 0,71546 \\
\hline A9 & 0,59262 & 0,23213 & 0,75395 \\
\hline A10 & 0,82754 & 0,24025 & 0,97353 \\
\hline A11 & 0,75431 & 0,24465 & 0,92639 \\
\hline A12 & 0,77089 & 0,23084 & 0,89767 \\
\hline A13 & 0,56687 & 0,23743 & 0,74890 \\
\hline A14 & 0,84304 & 0,24295 & 0,99470 \\
\hline A15 & 0,77181 & 0,24468 & 0,94098 \\
\hline A16 & 0,77382 & 0,24468 & 0,94265 \\
\hline A17 & 0,67565 & 0,23288 & 0,82505 \\
\hline A18 & 0,70359 & 0,23250 & 0,84701 \\
\hline A19 & 0,76609 & 0,24275 & 0,93032 \\
\hline A20 & 0,23958 & 0,08202 & 0,00000 \\
\hline & & & \\
\hline
\end{tabular}

\begin{tabular}{|c|c|}
\hline SIRA & $\begin{array}{c}\text { Sj } \\
\text { Değeri }\end{array}$ \\
\hline A20 & 0,23958 \\
\hline A5 & 0,28168 \\
\hline A1 & 0,48135 \\
\hline A6 & 0,48505 \\
\hline A3 & 0,49835 \\
\hline A7 & 0,49939 \\
\hline A2 & 0,50660 \\
\hline A8 & 0,53189 \\
\hline A4 & 0,55703 \\
\hline A13 & 0,56687 \\
\hline A9 & 0,59262 \\
\hline A17 & 0,67565 \\
\hline A18 & 0,70359 \\
\hline A11 & 0,75431 \\
\hline A19 & 0,76609 \\
\hline A12 & 0,77089 \\
\hline A15 & 0,77181 \\
\hline A16 & 0,77382 \\
\hline A10 & 0,82754 \\
\hline A14 & 0,84304 \\
\hline & \\
\hline
\end{tabular}

\begin{tabular}{|c|c|}
\hline SIRA & $\begin{array}{c}\text { Rj } \\
\text { Değeri }\end{array}$ \\
\hline A20 & 0,08202 \\
\hline A5 & 0,09013 \\
\hline A6 & 0,17622 \\
\hline A1 & 0,20048 \\
\hline A3 & 0,20748 \\
\hline A2 & 0,21015 \\
\hline A4 & 0,21771 \\
\hline A7 & 0,22714 \\
\hline A12 & 0,23084 \\
\hline A9 & 0,23213 \\
\hline A18 & 0,23250 \\
\hline A17 & 0,23288 \\
\hline A8 & 0,23598 \\
\hline A13 & 0,23743 \\
\hline A10 & 0,24025 \\
\hline A19 & 0,24275 \\
\hline A14 & 0,24295 \\
\hline A11 & 0,24465 \\
\hline A15 & 0,24468 \\
\hline A16 & 0,24468 \\
\hline & \\
\hline
\end{tabular}

\begin{tabular}{|c|c|}
\hline SIRA & $\begin{array}{c}\text { Qj } \\
\text { Değeri }\end{array}$ \\
\hline A20 & 0,00000 \\
\hline A5 & 0,05983 \\
\hline A6 & 0,49296 \\
\hline A1 & 0,56447 \\
\hline A3 & 0,60007 \\
\hline A2 & 0,61510 \\
\hline A7 & 0,66134 \\
\hline A4 & 0,68013 \\
\hline A8 & 0,71546 \\
\hline A13 & 0,74890 \\
\hline A9 & 0,75395 \\
\hline A17 & 0,82505 \\
\hline A18 & 0,84701 \\
\hline A12 & 0,89767 \\
\hline A11 & 0,92639 \\
\hline A19 & 0,93032 \\
\hline A15 & 0,94098 \\
\hline A16 & 0,94265 \\
\hline A10 & 0,97353 \\
\hline A14 & 0,99470 \\
\hline & \\
\hline
\end{tabular}




\section{Tablo 8: 2003-2013 Yılları Verileriyle Hesaplanan Qj Değerleri}

\begin{tabular}{|c|c|c|c|c|c|c|c|c|c|c|c|c|c|c|c|c|c|c|c|}
\hline \multicolumn{2}{|c|}{2003} & \multicolumn{2}{|c|}{2004} & \multicolumn{2}{|c|}{2005} & \multicolumn{2}{|c|}{2007} & \multicolumn{2}{|c|}{2008} & \multicolumn{2}{|c|}{2009} & \multicolumn{2}{|c|}{2010} & \multicolumn{2}{|c|}{2011} & \multicolumn{2}{|c|}{2012} & \multicolumn{2}{|c|}{2013} \\
\hline \begin{tabular}{c|}
$\mathbf{Q j}$ \\
Değeri
\end{tabular} & SIRA & $\begin{array}{c}Q \mathbf{Q j} \\
\text { Değeri }\end{array}$ & SIRA & $\begin{array}{c}\text { Qj } \\
\text { Değeri }\end{array}$ & SIRA & $\begin{array}{c}\mathbf{Q j} \\
\text { Değeri }\end{array}$ & SIRA & $\begin{array}{c}\mathrm{Qj} \\
\text { Değeri }\end{array}$ & SIRA & $\begin{array}{c}\text { Qj } \\
\text { Değeri }\end{array}$ & SIRA & $\begin{array}{c}\text { Qj } \\
\text { Değeri }\end{array}$ & SIRA & $\begin{array}{c}Q j \\
\text { Değeri }\end{array}$ & SIRA & $\begin{array}{c}Q \mathbf{Q j} \\
\text { Değeri }\end{array}$ & SIRA & $\begin{array}{c}Q j \\
\text { Değeri }\end{array}$ & SIRA \\
\hline 0,00846 & A20 & 0,01262 & A20 & 0,00000 & A20 & 0 & A20 & 0 & A20 & 0 & A20 & 0,03857 & A5 & 0,06363 & A5 & 0 & A5 & 0,00509 & A5 \\
\hline 0,02819 & A5 & 0,05220 & A5 & 0,07982 & A5 & 0,10669 & A5 & 0,10042 & A5 & 0,03115 & A5 & 0,04605 & A20 & 0,11099 & A20 & 0,14736 & A20 & 0,11126 & A20 \\
\hline 0,24537 & A6 & 0,32158 & A6 & 0,50467 & A6 & 0,52109 & A6 & 0,52863 & A6 & 0,47282 & A6 & 0,40452 & A6 & 0,46346 & A6 & 0,40672 & A6 & 0,52533 & A6 \\
\hline 0,31881 & A1 & 0,40644 & A1 & 0,61746 & A1 & 0,55373 & A1 & 0,54836 & A1 & 0,54456 & A1 & 0,54817 & A1 & 0,55308 & A1 & 0,55487 & A1 & 0,55332 & A1 \\
\hline 0,34322 & A3 & 0,44677 & A2 & 0,65491 & A3 & 0,59419 & A3 & 0,59773 & A2 & 0,59078 & A2 & 0,63622 & A2 & 0,63108 & A2 & 0,57856 & A8 & 0,6211 & A8 \\
\hline 0,34935 & A2 & 0,45139 & $\mathbf{A 3}$ & 0,67572 & A2 & 0,59658 & A2 & 0,61789 & A3 & 0,63581 & A3 & 0,66679 & A7 & 0,63295 & A8 & 0,63222 & A7 & 0,6301 & A13 \\
\hline 0,38896 & A4 & 0,49640 & A4 & 0,73151 & A7 & 0,65628 & A7 & 0,64774 & A7 & 0,66834 & A8 & 0,6728 & A8 & 0,66654 & A7 & 0,63548 & A13 & 0,63096 & A2 \\
\hline 0,39184 & A7 & 0,50095 & A7 & 0,73574 & A4 & 0,667 & A4 & 0,6628 & A8 & 0,67944 & A7 & 0,70159 & A3 & 0,70481 & A13 & 0,63587 & A2 & 0,64241 & A7 \\
\hline 0,39350 & A8 & 0,50251 & A8 & 0,75635 & A8 & 0,66849 & A8 & 0,67984 & A4 & 0,67953 & A4 & 0,70515 & A13 & 0,70694 & A3 & 0,66444 & A3 & 0,66608 & A3 \\
\hline 0,42289 & A13 & 0,55136 & A13 & 0,77494 & A13 & 0,74785 & A9 & 0,73976 & A13 & 0,69523 & A13 & 0,71726 & A4 & 0,72264 & A4 & 0,74311 & A4 & 0,73367 & A4 \\
\hline 0,43776 & A9 & 0,56329 & A9 & 0,81078 & A9 & 0,76379 & A13 & 0,78801 & A9 & 0,7825 & A9 & 0,77149 & A9 & 0,78834 & A9 & 0,7509 & A9 & 0,73828 & A9 \\
\hline 0,47411 & A17 & 0,61139 & A17 & 0,87128 & A17 & 0,83821 & A17 & 0,83028 & A12 & 0,85985 & A12 & 0,80877 & A12 & 0,82397 & A19 & 0,76851 & A18 & 0,81727 & A18 \\
\hline 0,48814 & A18 & 0,63830 & A11 & 0,91359 & A18 & 0,84171 & A18 & 0,83676 & A17 & 0,87387 & A17 & 0,85947 & A17 & 0,82888 & A17 & 0,79187 & A19 & 0,82596 & A19 \\
\hline 0,50223 & A16 & 0,64672 & A18 & 0,93925 & A16 & 0,84602 & A12 & 0,83741 & A19 & 0,89026 & A19 & 0,86861 & A18 & 0,83066 & A18 & 0,80516 & A17 & 0,82969 & A12 \\
\hline 0,51950 & A11 & 0,66149 & A16 & 0,93973 & A11 & 0,9049 & A19 & 0,83772 & A18 & 0,90956 & A14 & 0,88756 & A19 & 0,83892 & A12 & 0,81512 & A12 & 0,84676 & A17 \\
\hline 0,52124 & A14 & 0,67027 & A15 & 0,95310 & A15 & 0,91985 & A11 & 0,91536 & A11 & 0,91793 & A18 & 0,92803 & A14 & 0,88803 & A14 & 0,84813 & A14 & 0,89415 & A14 \\
\hline 0,54084 & A15 & 0,68135 & A14 & 0,96072 & A12 & 0,93171 & A14 & 0,91884 & A14 & 0,93371 & A11 & 0,9394 & A11 & 0,90909 & A10 & 0,94604 & A15 & 0,94709 & A10 \\
\hline 0,54748 & A12 & 0,68438 & A12 & 0,97066 & A10 & 0,93336 & A16 & 0,9687 & A16 & 0,98499 & A10 & 0,96396 & A10 & 0,91235 & A11 & 0,95704 & A11 & 0,96827 & A15 \\
\hline 0,58469 & A10 & 0,69424 & A10 & 0,98804 & A14 & 0,96627 & A15 & 0,98084 & A10 & 0,98532 & A16 & 0,99487 & A16 & 0,95338 & A15 & 0,96587 & A10 & 0,96931 & A11 \\
\hline 1,00000 & A19 & 1,00000 & A19 & 0,99438 & A19 & 0,98353 & A10 & 0,98415 & A15 & 0,99337 & A15 & 1 & A15 & 1 & A16 & 1 & A16 & 1 & A16 \\
\hline
\end{tabular}


2003 ve 2013 yılları arasında, her yıl için ayrı ayrı yapılan VIKOR yöntemi uygulaması sonucunda aşağıdaki tablo elde edilmiştir. Tabloda ülkeler uygulamanın sonucunda elde edilen ekonomik performans sıralamasına göre sıralanmıştır.

Tablo 9: Yıllara Göre Uzlaşık Çözümler

\begin{tabular}{|c|c|}
\hline Yılı & Uzlaşı Çözüm \\
\hline 2003 & Japonya \\
\hline 2004 & Japonya ve Almanya \\
\hline 2005 & $\begin{array}{c}\text { AB Komisyonu, ABD, Japonya, } \\
\text { Almanya, İngiltere, Fransa }\end{array}$ \\
\hline $2006-2007-2008$ & ABD ve AB Komisyonu \\
\hline 2009 & ABD \\
\hline 2010 & Almanya ve Japonya \\
\hline 2011 & Almanya \\
\hline 2012 & ABD ve AB Komisyonu \\
\hline 2013 & ABD \\
\hline
\end{tabular}

\section{SONUÇ VE ÖNERILER}

VIKOR yöntemi uygulamasında 11 yıllık ekonomik göstergeler kullanılarak elde edilen sonuçlara göre 2003 yılında Japonya'nın en iyi ekonomik performansa sahip uzlaşık çözüm olarak elde edilmiştir. Bu durum Japonya'nın 2003 yılındaki ekonomik göstergelerinden GSYH ve Dış Ticaret Hacminin yüksekliği ve düşük enflasyon oranıyla ilişkilendirilebilir. 2004 yılında Japonya'nın yanında Almanya uzlaşı çözüm kümesinde yer almıştır. Almanya'nın bu çıkışı geçmiş yıllardaki gerileyen ekonomisini yeniden güçlendirdiğini göstermektedir. 2005, 2006, 2007, 2008 ve 2012 yıllarında AB Komisyonunun en yüksek ekonomik performansa sahip olduğu görülmüştür. Bunu sağlayan öncelikle AB Komisyonu adı altında birçok Avrupa Birliği ülkesinin G20 içerisinde temsil edilmesi ve dolayısıyla en yüksek kriter ağırlığına sahip olan GSYH'nin, diğer G20 ülkelerine göre en yüksek olmasına bağlanabilir. AHP temelli VIKOR yönteminin bütün yıllar üzerinde uygulanması sonucunda; 2009, 2012 ve 2013 yıllarında, ABD'nin 2008 küresel ekonomik krizinin temeli olan ülke olmasına rağmen, G20 ülkeleri arasında en iyi ekonomik performansa sahip alternatif olduğu görülebilir. 2006, 2007 ve 2008 yıllarında ise en iyi ekonomik performansa sahip ikinci ülke olduğu tespit edilmiştir. 2005, 2006, 2007, 2008 yıllarında AB Komisyonu ve ABD'nin ekonomik verileri olumlu düzeyde giderken, 2009 yılı sonrasında AB Komisyonu'nun ekonomik verilerinin olumsuz etkilendiği ve uzlaşık çözüm olmaktan çıtı̆̆g görülmüşsür. 2010 yılında ABD'nin uzlaşık çözüm kümesindeki yerini, Almanya ve Japonya'ya, 2011 yılında ise sadece Almanya'ya bırakması, ABD'nin dış ticaret hacmindeki daralmayı Almanya ve Japonya'nın firsata çevirmesiyle ilişkilendirilebilir. 2012 yılında ABD ve AB Komisyonu ekonomik verilerindeki yükseliş nedeniyle uzlaşık çözüm kümesinde yer alırken, Almanya'nın ve 2013 yılında da AB Komisyonu'nun yer almaması 2012 Euro Krizi ile bağdaştırılabilir. 
Türkiye, yapılan hesaplamalarda C1 ve C2 koşullarını sağlamadığ1 için uzlaşık ideal çözüm kümesinde yer almamıştır. Ancak çözüm sıralamasını veren $\mathrm{Q}_{\mathrm{j}}$ sıralamasına göre Tablo 8'de de görüldüğü üzere, 2007 yılında 20. sırada, 2003, 2004,2006, 2008 ve 2012 yıllarında 19. sirada, 2005, 2009 ve 2010 yıllarında 18. sirada, 2011 ve 2013 yıllarında 17. sirada olduğu görülmektedir. Türkiye'nin ekonomik performansının G20 ülkeleri arasındaki sıralaması, 2008 küresel krizi öncesinde 19. ve 20. sıradayken, kriz sonrasında 17. siraya kadar yükseldiği gözlenmiştir. Türkiye'nin uygulamış olduğu mali ve stratejik politikalar ile Türkiye bankalarının, kurumsallaşma sürecini diğer ülke bankalarına göre daha hızlı ve başarılı bir şekilde gerçekleştirdiği ve krizden kötü etkilenmediği söylenebilir. En yüksek kriter ağırlığı değerlerine sahip olan GSYH ile Kişi Başına Düşen GSYH kriterlerinde Türkiye, diğer ülkelere göre düşük performansa sahip olduğundan bu durumun sıralamada da doğrudan etkili olduğu görülebilir. Ancak ekonomik göstergelerin yıllar itibariyle olumlu düzeyde ilerlemesi ekonomik performans sıralamasındaki artış ile ve 2012 yılındaki düşüş ise 2012 Euro Krizi ile ilişkilendirilebilir.

Tablo 10: Türkiye'nin 2003-2013 Yılları Arasındaki Yıllara Ait $Q_{j}$ Değerleri

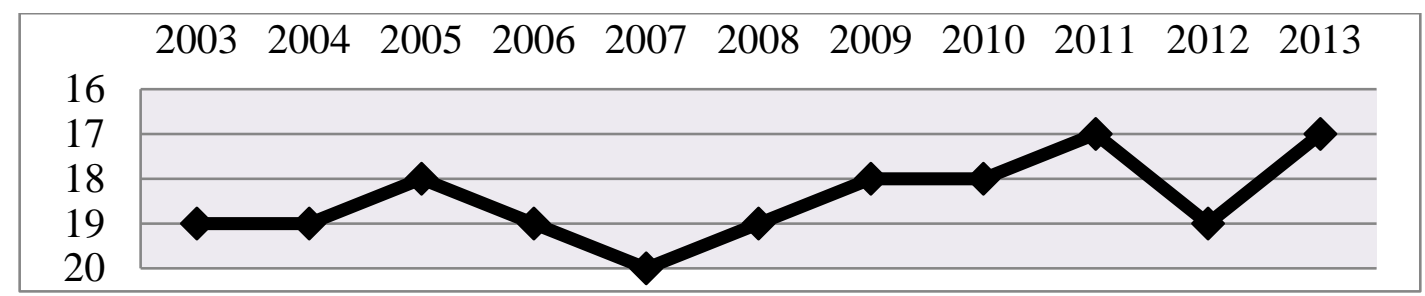

Hesaplamalar sonucunda ortaya çıan sonuçlar ile daha önce bu alanda benzer yöntemlerle yapılmış çalışmaların sonuçları karşılaştırıldığında elde edilen sonuçlara yakın sonuçlara ulaşıldığ 1 görülmüştür. Literatür taramasında, daha önce yapılmış çalışmaların sonucu ile bu çalışmayla elde edilen sonuçlar arasında bazı farklılaşmaların gözlenmesinin nedeni ise hesaplama yöntemleri ve kriterlere atanan ağırlık değerlerinden kaynaklanan farklılıklar olduğu söylenebilir. Dünya ekonomik krizi öncesi ve sonrasındaki yıllara ait sayısal veriler kullanılarak yapılan uygulama ile Türkiye'nin ekonomik kriz ile baş etme yöntemlerini başarılı bir şekilde uygulamış olduğu yorumu yapılabilir. Çalışmada yer alan uygulama konusuna benzer, daha önce sınırlı sayıda çalışma yapılmış olduğundan, ekonomik performans konusunun, çok kriterli karar verme yöntemleriyle birlikte daha çok işlenmesi önerilir. Bu çalışmaya benzer olarak yapılacak olan çalışmalarda, ekonomik performans ölçümü, farklı birkaç yöntem bir arada uygulanarak, yöntemlerin verdiği sonuçlar kıyaslanabilir.

\section{KAYNAKÇA}

Ada, E. , Kazançoğlu, Y. ve Aracıoğlu, F. (2005). "Stratejik Rekabet Üstünlüğü Sağlamada Tedarikçi Seçiminin Analitik Hiyerarşik Süreç İle Gerçekleştirilmesi”, V. Ulusal Üretim Araştırmaları Sempozyumu, İstanbul Ticaret Üniversitesi, 25-27 Kasım 2005, ss. 605-611.

Aghdaie, M. H. , Zolfani, S. H. \& Zavadskas, E. K. (2014). "Synergies of Data Mining and Multiple Attribute Decision Making”, Procedia-Social and Behavioral Sciences, 110, ss. 767-776.

Akman, C. (2010). 2008 Küresel Ekonomik Krizine Tarihsel ve Teorik Açıdan Bir Yaklaşım, Doktora Tezi, İstanbul: İstanbul Üniversitesi Sosyal Bilimler Enstitüsü.

Akman, G. (2015). "Evaluating Suppliers to Include Green Supplier Development Programs Via Fuzzy C-Means and VIKOR Methods", Computers \& Industrial Engineering, 86, ss. 69-82.

Alantar, D. (2008). "Küresel Finansal Kriz: Nedenleri ve Sonuçları Üzerine Bir Değerlendirme”, Maliye Finans Yazıları Dergisi, Say1: 81, ss. 1-10, Ekim 2008. 
Altınok, S. (2004). İktisada Giriş, Konya: Atlas Kitabevi, Genişletilmiş 3. Baskı.

Altuntepe, N. (2013). "2008 Küresel Krizinin Ülkelerin İstihdam Yapısı Üzerine Etkilerinin Dinamik Bir Analizi”, Süleyman Demirel Üniversitesi Dergisi, ss. 129-145, Isparta.

Ar, İ. M., Baki, B. ve Özdemir, F. (2014). "Kuruluş Yeri Seçiminde Bulanık AHS-VIKOR Yaklaşımının Kullanımı: Otel Sektöründe Bir Uygulama”, Uluslararası İktisadi ve İdari İncelemeler Dergisi, Y11:7 Sayı:13, Yaz, ISSN: 1307-9832, ss. 93-114.

Aydın, Ö. , Öznehir, S. ve Akçalı, E. (2009). "Ankara İçin Optimal Hastane Yeri Seçiminin Analitik Hiyerarşi Süreci İle Modellenmesi”, Süleyman Demirel Üniversitesi İktisadi ve İdari Bilimler Fakültesi Dergisi, Cilt: 14 Sayı: 2, ss. 69-86, Isparta.

Ballı, S. , Karasulu, B. ve Korukoğlu, S. (2007). "En Uygun Otomobil Seçimi Problemi İçin Bir Bulanık PROMETHEE Yöntemi Uygulaması”, Dokuz Eylül Üniversitesi İktisadi ve İdari Bilimler Fakültesi Dergisi, Cilt: 22, Sayı: 1, ss: 139-147, İzmir.

Bali, Ö. (2013). "Bulanık Boyut Analizi ve Bulanık VIKOR İle Bir ÇNKV Modeli: Personel Seçimi Problemi”, KHO Bilim Dergisi, Cilt: 23 Sayı: 2, ss. 125-149.

Baykal, İ. Ö. (2007). Çok Ölçütlü Karar Verme Yöntemlerinin Personel Seçimi Problemine Uygulanması, Yüksek Lisans Tezi, İstanbul: Galatasaray Üniversitesi Fen Bilimleri Enstitüsü.

Büyüközkan, G. \& Ruan, D. (2008). Evaluation of Software Development Projects Using Fuzzy Multi-Criteria Decision Approach, (http://www.sciencedirect.com/science/article/pii/S0378475407003539) Erişim Tarihi:17.10.2016.

Can, Ş. ve Arıkan, F. (2014). "Bir Savunma Sanayi Firmasında Çok Kriterli Alt Yüklenici Seçim Problemi ve Çözümü”, Gazi Üniversitesi Mühendislik ve Mimarlık Fakültesi Dergisi, Cilt: 29, No:4, ss.645-654, Ankara.

Chan, F. T. S. , Chan, H. K. , Lau, H. C. V. \& Ip, R.W. L. (2006). "An AHP Approach in Benchmarking Logistics Performance of The Postal Industry", Benchmarking: An International Journal, Cilt: 13, No: 6, ss. 636-661.

Chen, J.-K. \& Chen, I.-S. (2008). "VIKOR Method for Selecting Universities for Future Development Based On Innovation", Journal of Global Business Issues, Say1: 2, ss. 53-59.

Chen, L. Y. \& Wang, T.-C. (2009). "Optimizing Partners Choice in IS/IT Outsourcing Projects: The Strategic Decision of Fuzzy VIKOR”, Int. J. Production Economics, Say1: 120, ss. 233-242.

Chiu, Y.-J. \& Chen, Y.-W. (2007). "Using AHP in Patent Valuation”, Mathematical and Computer Modelling, 46, ss. 1054-1062.

Chu, M.T., Shyu, J., Tzeng, G.H. \&Khosla, R. (2007). "Comparison Among Three Analytical Methods for Knowledge Communities Group-Decision Analysis”, Expert Systems with Applications, 33, ss. 1011-1024.

Dağdeviren, M. (2007). "Bulanık Analitik Hiyerarşi Prosesi ile Personel Seçimi ve Bir Uygulama", Gazi Üniversitesi Mühendislik ve Mimarlık Fakültesi Dergisi, Cilt: 22, No: 4, ss. 791-799, Ankara.

Eğilmez, M. (2012). (http://www.mahfiegilmez.com/2012/01/ekonomik-buyume-ne-demektir.html) Erişim Tarihi: 28.10 .2016

Eğilmez, M. (2012). (http://www.mahfiegilmez.com/2012/01/turkiyede-kamu-kesimi-borcu.html) Erişim Tarihi: 28.10.2016

Ertek, T. (2008). Makroekonomiye Giriş, İstanbul: Beta Yayıncılık, 3. Baskı.

Ertuğrul, İ. ve Karakaşoğlu, N. (2008). "Banka Şube Performanslarının VIKOR Yöntemi İle Değerlendirilmesi”, Endüstri Mühendisliği Dergisi, YA/EM 2008 Özel Sayıs1, Cilt: 20, Say1: 1, ss. 19-28.

Ferguson, N. (2009). The Ascent of Money: A Financial History of The World, London: Penguen Books, 2. Bask1.

Gök, M. (2015). G20 Ülkelerinin Enerji Göstergeleri Açısından Çok Kriterli Karar Verme Teknikleri İle Stralanması, Yüksek Lisans Tezi, Ankara: Ankara Üniversitesi Sosyal Bilimler Enstitüsü.

Göktürk, İ. F., Eryılmaz, A.Y., Yörür, B. ve Yuluğkural, Y. (2011). "Bir İşletmenin Tedarikçi Değerlendirme ve Seçim Probleminin Cözümünde AAS ve VIKOR Yöntemlerinin Kullanılması", Dumlupınar Üniversitesi Fen Bilimleri Enstitüsü Dergisi, Say1: 25, ss. 61-74, Kütahya.

Grossman, M. G. \& Helpman, E. (2003). "Dıș Ticaret, Bilgi Taşmaları ve Büyüme”, Celal Bavar Üniversitesi İkisadi ve Ídari Bilimler Dergisi, Cilt: 4, Sayı: 2, ss. 187-199, Manisa. 
Güngör, İ. ve İşler, B. D. (2005). “Analitik Hiyerarşi Yaklaşımı ile Otomobil Seçimi”, Zonguldak Karaelmas Üniversitesi Sosyal Bilimler Dergisi, Cilt: 1, Say1: 2, ss. 21-33, Zonguldak.

Herrig, R. \& Santomero, A. (1996). The Role of The Financial Sectör in Economic Performance, USD: Working Paper, University of Pensylvania.

Hull, J. C. (2013), The Credit Crunch of 2007, What Went Wrong? Why? What Lessons Can Be Learned?, (http://www2.rotman.utoronto.ca/ hull/ downloadablepublications/CreditCrunch.pdf, e.t.) Erişim Tarihi: 11.06.2016.

Jablonsky, J. (2007). "Measuring The Efficiency of Production Units by AHP Models", Mathematical and Computer Modelling, 46, ss. 1091-1098.

Karaatl1, M., Ömürbek, N. ve Köse, G. (2014). “Analitik Hiyerarşi Süreci Temelli TOPSIS ve VIKOR Yöntemleri İle Futbolcu Performanslarının Değerlendirilmesi”, Dokuz Eylül Üniversitesi İktisadi ve İdari Bilimler Fakültesi Dergisi, Cilt: 29, Sayı: 1, ss. 25-61, İzmir.

Kaya, P. , Çetin, E. İ. ve Kuruüzüm, A. (2011). "Çok Kriterli Karar Verme İle Avrupa ve Aday Ülkelerinin Yaşam Kalitesinin Analizi”, İstanbul Üniversitesi İktisat Fakültesi Ekonometri ve İstatistik Dergisi, 12. Uluslararas1 Ekonometri, Yöneylem Araştırması, İstatistik Sempozyumu Özel Sayısı, Sayı: 13, ss. 80-94.

Kılıçoğulları, P., Özcan, B. ve Ertuğ, B. (2009). "Bir Akaryakıt İstasyonu Seçiminde ELECTRE Yönteminin Kullanılması", Yöneylem Araştırması ve Endüstri Mühendisliği 29.Ulusal Kongresi, ss. 1-6.

Korhonen, P. \& Topdagi, H. (2003). "Performance of The AHP in Comparison of Gains and Losses", Mathematical and Computer Modelling, 37, ss. 757-766.

Kwiesielewicz, M. \& Uden, E. V. (2004). "Inconsistent and Contradictory Judgements in Pairwaise Comparison Method in The AHP”, Computers \& Operations Research, 31, ss. 713-719.

Mohanty, P. P. \& Mahapatra, S.S. (2014). "A Compromise Solution by VIKOR Method for Ergonomically Designed Product with Optimal Set of Design Characteristics”, Procedia Materials Science, 6, ss. 633-640.

Mikaeil, R. , Yousefi, R. \& Ataei, M. (2011). "Sawability Ranking of Carbonate Rock Using Fuzzy Analytical Hierarchy Process and TOPSIS Approaches”, Scientia Iranica, B, 18 (5), ss. 1106-1115.

Obstfeld, M. \& Rogoff, K. (1996). Foundations of International Macroeconomics, London: The MIT Press.

Opricovic, S. \& Tzeng, G. H. (2004). "Compromise Solution by MCDM Methods: A Comparative Analysis of VIKOR and TOPSIS”, European Journal of Operational Research, Cilt: 156, No: 2, ss. 445-455.

Opricovic, S. \& Tzeng, G. H. (2007). "Extended VIKOR Method in Comparison with Other Outranking Methods", European Journal of Operational Research, Cilt: 178, ss. 514-529.

Özden, Ü. H. (2012). “AB’ye Üye Ülkelerin ve Türkiye’nin Ekonomik Performanslarına Göre VIKOR Yöntemi İle Siralanması”, İstanbul Ticaret Üniversitesi Sosyal Bilimler Dergisi Yll: 11 Sayl: 21 Bahar 2012 / 1 ss.455-468.

Özden, Ü. H. , Başar, Ö. D. ve Kalkan, B. S. (2012). “IMKB'de İşlem Gören Çimento Sektöründeki Şirketlerin Finansal Performanslarının VIKOR Yöntemi İle Sıralanması”, İstanbul Üniversitesi İktisat Fakültesi Ekonometri ve Istatistik Dergisi, Say1: 17, ss. 23-44.

Özyörük, B. , Özcan E. C. (2008). "Analitik Hiyerarşi Sürecinin Tedarikçi Seçiminde Uygulanması: Otomotiv Sektöründe Bir Örnek", Süleyman Demirel Üniversitesi İktisadi ve İdari Bilimler Fakültesi Dergisi, Y11: 2008, Cilt:13, Say1:1 ss.133-144.

Palaz, H. ve Kovancı, A. (2008). "Türk Deniz Kuvvetleri Denizaltılarının Seçiminin AHP İle Değerlendirilmesi”, Havacılık ve Uzay Teknolojileri Dergisi, Cilt: 3, Sayı: 3, ss. 53-60.

Perçin, S. ve Ayan, T. Y. (2010). "AHS ve Bulanık PROMETHEE Yaklaşımlarıyla Esnek Üretim Sistemleri Seçimi”, Marmara Üniversitesi İktisadi ve İdari Bilimler Fakültesi Dergisi, Say1: 2, ss. 555-575, İstanbul.

Sakthivel, G. , Ilangkumaran, M. \& Gaikwad, A. (2015). "A Hybrid Multi-Criteria Decision Modeling Approach for The Best Biodiesel Blend Selection Based on ANP-TOPSIS Analysis", Ain Shams Engineering Journal, Sayı: 6, ss. 239-256.

Saaty, T. L. (1980). The Analytic Hierarchy Process, USA: McGraw Hill.

Saaty, T. L. \& Özdemir, M. S. (2003). "Why The Magic Number Seven Plus or Minus Two", Mathematical and Computer Modelling, Say1: 38, ss. 233-244.

Saunders, A. \& Cornett, M. M. (2001). Financial Markets and Institutions, New York: McGraw-Hill Higher Education. 
Sekhar, C., Patwardhan, M. \&Vyas,V. (2015). “A DELPHI-AHP-TOPSIS Based Framework for The Prioritization of Intellectual Capital Indicators: A Smes Perspective”, Procedia - Social and Behavioral Sciences, 189, ss. 275284.

Selim, S. , Purtaş, Y. ve Uysal, D. (2014). "G-20 Ülkelerinde Eğitim Harcamalarının Ekonomik Büyüme Üzerindeki Etkisi”, Optimum Ekonomi ve Yönetim Bilimleri Dergisi, 1(2), ss. 93-102.

Soba, M. ve Bildik, T. (2013). "İlçelerde Fakülte Yeri Seçiminin Analitik Hiyerarşi Süreci Metodu İle Belirlenmesi”, Kafkas Üniversitesi İktisadi ve İdari Bilimler Fakültesi Dergisi, Cilt: 4, Sayı: 5, ISSN: 1309-4289, ss. 51-63, Kars.

Soner, S. ve Önüt, S. (2006). "Çok Kriterli Tedarikçi Seçimi: Bir ELECTRE-AHP Uygulaması”, Yıldız Teknik Üniversitesi Mühendislik ve Fen Bilimleri Dergisi, Sayı: 4, ss. 110-120, İstanbul.

Tarım, Ş. (2011). “G20’nin Kuruluşundan Günümüze Gelişimi”, Ekonomik Forum, Temmuz 2011, ss. 84-89.

TCMB, (2015). G20 Platformu ve 2015 Türkiye Dönem Başkanlığı, TCMB Yayınları, http://www. tcmb. gov. tr adresinin basılı yayını kullanılmıştır.

Tyagi, M., Kumar, P. \& Kumar, D. (2014). “A Hybrid Approach Using AHP-TOPSIS for Analyzing e-SCM Performance”, Procedia Engineering, 97, ss. 2195-2203.

Tzeng, G. H. , Lin, C. W. \& Opricovic, S. (2005). "Multi-Criteria Analysis of Alternative-Fuel Buses for Public Transportation”, Energy Policy, 33, ss. 1373-1383.

Ustasüleyman, T. (2009). "Bankacılık Sektöründe Hizmet Kalitesinin Değerlendirilmesi: AHS-TOPSIS Yöntemi”, Bankacılar Dergisi, Say1: 69, ss. 33-43.

Ünal, Ö. F. (2010). Analitik Hiyerarşi Prosesi ile Yetkinlik Bazlı İnsan Kaynakları Yöneticisi Seçimi, Doktora Tezi, Isparta: Süleyman Demirel Üniversitesi Sosyal Bilimler Enstitüsü.

Wasserstom, E. (2008). “On The Financial Crisis: It's Not Just Weak Oversight”, The New York Times, 17 Eylül 2008.

Wind, Y. \& Saaty, T. L. (1980). "Marketing Applications of The Analytic Hierarchy Process", Management Science, 26(7), ss. 641-658.

Yıldız, A. ve Deveci, M. (2013). "Bulanık VIKOR Yöntemine Dayalı Personel Seçim Süreci”, Ege Akademik Bakış Dergisi, Cilt: 13, Say1: 4, Ekim, 2013, ss. 427-436.

Yurdakul, M. ve İpek, A. Ö. (2005). "Malzeme Taşıma Sistemlerinin Seçilmesine Yönelik Bir Karar Destek Sistemi Geliştirilmesi”, Gazi Üniversitesi Mühendislik Mimarlık Fakültesi Dergisi, Cilt: 20, No: 2, ss. 171-181, Ankara.

Zaim, S. (1997). Çalışma Ekonomisi, İstanbul: Filiz Kitapevi, 10. Basım. 


\section{EK}

\section{EK 1: Tutarlılık Oranı Hesaplaması}

$\left[\begin{array}{lllllllll}1,00 & 3,00 & 3,00 & 3,00 & 1,00 & 5,00 & 5,00 & 3,00 & 5,00 \\ 0,33 & 1,00 & 1,00 & 1,00 & 0,33 & 3,00 & 3,00 & 1,00 & 3,00 \\ 0,33 & 1,00 & 1,00 & 1,00 & 0,33 & 3,00 & 3,00 & 1,00 & 3,00 \\ 0,33 & 1,00 & 1,00 & 1,00 & 0,33 & 3,00 & 3,00 & 1,00 & 3,00 \\ 1,00 & 3,00 & 3,00 & 3,00 & 1,00 & 5,00 & 5,00 & 3,00 & 5,00 \\ 0,20 & 0,33 & 0,33 & 0,33 & 0,20 & 1,00 & 1,00 & 0,33 & 1,00 \\ 0,20 & 0,33 & 0,33 & 0,33 & 0,20 & 1,00 & 1,00 & 0,33 & 1,00 \\ 0,33 & 1,00 & 1,00 & 1,00 & 0,33 & 3,00 & 3,00 & 1,00 & 3,00 \\ 0,20 & 0,33 & 0,33 & 0,33 & 0,20 & 1,00 & 1,00 & 0,33 & 1,00\end{array}\right] \times\left[\begin{array}{l}0,24468 \\ 0,09915 \\ 0,09915 \\ 0,09915 \\ 0,24468 \\ 0,03802 \\ 0,03802 \\ 0,09915 \\ 0,03802\end{array}\right]=$

\begin{tabular}{|c|c|c|c|c|c|c|c|}
\hline \multirow{9}{*}{$=0,24468 x$} & 1,00 & \multirow{9}{*}{+} & \multirow{9}{*}{\multicolumn{2}{|c|}{$0,09915 x$}} & 3,00 & \multirow{9}{*}{$+0,09915 x$} & 3,00 \\
\hline & 0,33 & & & & 1,00 & & 1,00 \\
\hline & 0,33 & & & & 1,00 & & 1,00 \\
\hline & 0,33 & & & & 1,00 & & 1,00 \\
\hline & 1,00 & & & & 3,00 & & 3,00 \\
\hline & 0,20 & & & & 0,33 & & 0,33 \\
\hline & 0,20 & & & & 0,33 & & 0,33 \\
\hline & 0,33 & & & & 1,00 & & 1,00 \\
\hline & 0,20 & & & & 0,33 & & 0,33 \\
\hline \multirow{9}{*}{$0,09915 \mathrm{x}$} & 3,00 & \multirow{9}{*}{\multicolumn{3}{|c|}{0,24468}} & 1,00 & \multirow{9}{*}{$+0,03802 x$} & 5,00 \\
\hline & 1,00 & & & & 0,33 & & 3,00 \\
\hline & 1,00 & & & & 0,33 & & 3,00 \\
\hline & 1,00 & & & & 0,33 & & 3,00 \\
\hline & 3,00 & & & & 1,00 & & 5,00 \\
\hline & 0,33 & & & & 0,20 & & 1,00 \\
\hline & 0,33 & & & & 0,20 & & 1,00 \\
\hline & 1,00 & & & & 0,33 & & 3,00 \\
\hline & 0,33 & & & & 0,20 & & 1,00 \\
\hline
\end{tabular}




$$
\begin{aligned}
& 0,03802 \times\left[\begin{array}{c}
5,00 \\
3,00 \\
3,00 \\
3,00 \\
5,00 \\
1,00 \\
1,00 \\
3,00 \\
1,00
\end{array}\right]+0,0991 \times\left[\begin{array}{c}
3,00 \\
1,00 \\
1,00 \\
1,00 \\
3,00 \\
0,33 \\
0,33 \\
1,00 \\
0,33
\end{array}\right]+0,03802 \times\left[\begin{array}{l}
5,00 \\
3,00 \\
3,00 \\
3,00 \\
5,00 \\
1,00 \\
1,00 \\
3,00 \\
1,00
\end{array}\right]= \\
& =\left[\begin{array}{l}
2,24939 \\
0,90023 \\
0,90023 \\
0,90023 \\
2,24939 \\
0,34280 \\
0,34280 \\
0,90023 \\
0,34280
\end{array}\right] \\
& 2,24939 / 0,24468=9,19324 \\
& 0,90023 / 0,09915=9,07964 \\
& 0,90023 / 0,09915=9,07964 \\
& 0,90023 / 0,09915=9,07964 \\
& 2,24939 / 0,24468=9,19324 \\
& 0,34280 / 0,03802=9,01702 \\
& 0,34280 / 0,03802=9,01702 \\
& 0,90023 / 0,09915=9,07964 \\
& 0,34280 / 0,03802=9,01702 \\
& \lambda \text { maks }=(9,19324+9,07964+9,07964+9,07964+9,19324+ \\
& 9,01702+9,01702+9,07964+9,01702) / 9=9,08401 \\
& C I=\frac{(\lambda \text { maks }-\mathrm{n})}{(\mathrm{n}-1)}=\frac{(9,0840-9)}{8}=0,01050 \\
& R I=\quad 1,45(\text { Tablodan }) \\
& \mathrm{CR}=\frac{C I}{R I}=\frac{0,01050}{1,45}=0,00724<0,1^{\prime} \text { dir. }
\end{aligned}
$$

